\title{
PENTINGNYA INTERPRETASI HAKIM DALAM MENYETUJUI PERMOHONAN IJIN POLIGAMI DI PENGADILAN AGAMA
}

\author{
Novita Setyoningrum, Dosen Fakultas Hukum Universitas Islam Balitar, Blitar, \\ E-mail: davafadil22@gmail.com, 0822-0842-3808
}

\begin{abstract}
Abstrak
Perkawinan merupakan peristiwa penting dalam kehidupan manusia. Dimana perkawinan adalah ikatan lahir dan batin antara seorang pria dan seorang wanita untuk menjadi suami istri yang bertujuan membentuk keluarga bahagia kekal abadi berdasarkan Ketuhanan Yang Maha Esa. Pada dasarnya azas perkawinan di Indonesia adalah azas monogami. Meskipun poligami tidak dilarang selama memenuhi syarat dan ketentuan yang berlaku sesuai dengan Pasal 4 ayat (1) dan ayat (2) Undang-Undang Nomor 1 Tahun 1974 tentang Perkawinan. Namun pada praktek dalam Pengadilan Agama, Penetapan Majelis Hakim sering kali tidak sesuai dengan ketentuan dari ijin Poligami itu sendiri yang telah ditentukan di dalam Pasal 4 dan Pasal 5 UU No. 1 Tahun 1974 mengenai syarat absolut dan alternatif dalam poligami. Penelitian ini menggunakan metode yuridis normatif yaitu dengan cara meneliti sumber pustaka dan pada data sekunder saja, yang berupa norma hukum tertulis. Harapan yang ingin disampaikan peneliti dalam penelitian ini adalah agar Majelis Hakim khususnya di Pengadilan Agama lebih jeli dan teliti dalam memberikan ijin poligami terhadap pemohon pelaku poligami.
\end{abstract}

KataKunci: Interpretasi Hakim, Persetujuan Ijin Poligami, Pengadilan Agama

\section{PENDAHULUAN}

\section{Latar Belakang}

Perkawinan berasal dari bahasa Arab zawwaja dan nakaha. Kedua kata yang digunakan al-Qur'an untuk menunjukkan perkawinan antara manusia (untuk orang muslim). Kata nakaha berarti menghimpun sedangkan kata zawwajja berarti pasangan. Jika dilihat dari sisi bahasa perkawinan adalah berhimpunnya 2 (dua) orang yang semula sendiri-sendiri menjadi satu kesatuan. Perkawinan pada dasarnya adalah mithsaqaan ghaliidzan (tali kuat) yang dipertahankan selamanya. Namun pada kenyataannya banyak perkawinan yang berakhir dengan perceraian sehingga tidak sesuai dengan tujuan perkawinan dimana selain memenuhi kebutuhan biologis, perkawinan juga bertujuan untuk memperoleh ketenangan hidup, memperoleh keturunan, dan menjalankan perintah Allah, serta menjaga kehormatan diri sendiri, anak, dan keluarga besar. ${ }^{1}$

Fenomena keretakan rumah tangga, perceraian terjadi disebabkan oleh dominasi hasrat biologis dimana perkawinan di Indonesia berlangsung di bawah mentaliats yang salah (errormentality) seperti di atas. ${ }^{2}$ Undang- Undang Perkawinan sudah berusia 44 tahun akan tetapi masih banyak warga Negara Indonesia yang tidak atau belum tersosialisasi dan diterapkan dengan baik. Hal ini dapat dilihat dari pola perilaku masyarakat Indonesia yang bertentangan dengan isi dari UU No 1/1974 tentang Perkawinan (UUP). Dimana umat Islam dengan tokoh panutan masing-masing yang bersifat mendua sebagian sadar dan mentaatinya, tetapi sebagian lagi meremehkan dan

\footnotetext{
${ }^{1}$ Khoiruddin Nasution, Hukum Perkawinan, Dilengkapi dengan UU Negara Muslim Kontemporer, Yogyakarta: Academia \& Tazzafa, 2005, hlm.38-47.

${ }^{2}$ Sjamsu Alam, Usia Perkawinan dalam Perspektif Filsafat Hukum dan Kontribusinya bagi Perkembangan Hukum Perkawinan Indonesia, Disertasi Program Doktor Filsafat, 2011, (belum diterbitkan), hlm.1.
} 
menganggap UU Perkawinan merupakan aturan Negara yang dianggap UUP dengan melakukan nikah, talak, rujuk, poligami diluar aturan perundang-undangan, yang telah diatur oleh Negara. Akhirnya timbul dualism hukum dengan standar ganda yang berbeda yaitu hukum agama dan hukum Negara dimana keduanya bisa saling bertentangan. Sah menurut agama belum tentu sah menurut Negara begitu pula sebaliknya. Masyarakat berpendapat UUP hanya berhubungan dengan Institusi Pemerintah saja, tidak berhubungan dengan hukum Islam sehingga jika dilanggarpun tidak berdosa, dimana daya paksa UUP sangat lemah sehingga tidak dapat memaksa setiap warga Negara Indonesia untuk mematuhinya dan dan memberikan sanksi hukum yang tegas kepada warga negaranya yang melanggar yang dicantumkan dalam undangundang.

Dalam hal tersebut diatas karena, perceraian, poligami, talak, rujuk, telah diatur dalam peraturan perundang-undangan dan tetap melibatkan peranan Majelis Hakim dalam proses Pengadilan, baik Pengadilan Agama maupun Pengadilan Negeri. Dalam karya ilmiah ini penulis secara spesifik akan membahas mengenai ijin poligami dan pentingnya peranan hakim dalam menginterpretasikan pemberian ijinter hadap pelaku poligami baik secara psikologis dan secara yuridisnya. Agar putusan tersebut dapat memberikan kemaslahatan bagi banyak pihak didalam rumah tangga yang melakukan poligami.

\section{RumusanMasalah}

1. Seberapa pentingkah interpretasi hakim dalam menyetujui permohonan ijin poligami di Pengadilan Agama?

2. Sudah idealkah pengaturan tentang ijin poligami menurut hukum Islam dan yang terdapat pada UU N0.1/1974 tentang Perkawinan?

\section{PEMBAHASAN}

Perkawinan tidak hanya suci namun juga indah. Sejak Tuhan menghendaki persatuan pria dan wanita yang diwujudkan secara mendalam didalam perkawinan, maka pada saat itu manusia terikat pada sebuah perjanjian untuk saling setia. Secara filosofi keindahan perkawinan terletak pada kesetiaan. Wujud indahnya kesetiaan tergambar dalam realitas bahwa suami istri harus jujur, terbuka, tidak menyimpan rahasia terhadap istri, menjaga perasaan istri, menjaga mentalitas istri pada saat istri mengalami ketidakstabilan, tidak berbuat semena-mena, tidak mabuk-mabukan, tidak main judi, dan mengasihi istri seperti suami mengasihi dirinya sendiri. Konflik dalam rumahtangga timbul dari berbagai hal. Perceraian seringkali jadi jalan pintasnya. Kurangnya komunikai yang baik menjadi saah satu faktornya juga. Dalam hal ini penulis akan membahas secara spesifik mengenai masalah rumahtangga yang banyak terjadi dikalangan masyarakat kita yaitu tentang poligami. Di dalam UUP poligami diperbolehkan dantidakdilarang namun aturannya dipersempit danterkesan dipersulit tetapi ini semua demi kebaikkan seluruh pihak yang bersangkutan. Pada asasnya perkawinan di Indonesia adalah asas monogami ini tertuang dalam Pasal 3 ayat (1) UUP yang menyatakan: "Pada asasnya dalam suatu perkawinan seorang pria hanya boleh 
mempunyai seorang istri. Seorang wanita hanya boleh mempunyai seorang suami." 3 Tetapi poligami juga diperbolehkan. Ini termaktub didalam Pasal 3 ayat (2) UUP yangmenyatakan: "Pengadilan dapat memberikan izin kepada seorang suami untuk beristri lebih dari seorang apabila dikehendaki oleh pihak-pihak bersangkutan. ${ }^{4}$

Dalam hal permohonan ijin mengenai poligami peranan seorang hakim di Pengadilan Agama adalah sangat penting. Dimana hakim akan menjadi seorang pengambil keputusan atas dikabulkannya permohonan izin poligami atau tidak. Ini tertuang didalam Pasal 4 ayat (1) dan ayat (2) UUP:

"Dalam seorang suami akan beristri lebih dari seorang, sebagaimana tersebut dalam Pasal 3 ayat (2) maka ia wajib mengajukan permohonan ke Pengadilan di daerah tempat tinggalnya;

hanya memberikan izin kepada seorang suami yang akan beristri lebih dari seorang apabila:

a.Istri tidak dapat menjalankan kewajibannya sebagai istri;

b.Istri mendapatkan cacat badan atau penyakit yang tidak dapat disembuhkan; c.Istri tidak dapat melahirkan keturunan.

Undang-Undang menyebutkan begitu pentingnya peranan hakim dalam memberikan ijin pada pemohon poligami. Maka dari itu interpretasi hakim sangat diperlukan dalam hal ini, agar tidak merugikan pihak-pihak yang bersangkutan dalam praktekpoligami. Putusan hakim dalam pengamatan penulis tidak hanya bersentuhan dengan aspek formil dan materiil dari hukum sebagai sebuah sistem. Putusan hakim tidak pula hanya semata-mata pertimbangan yang berdasarkan pada analisa-analisa non hukum yaitu aspek sosiologis, antropologis, dan psikologis. Lebih dari itu hakim bersentuhan langsung dengan aspek spiritualitas, yang mana putusan hakim didasarkan pada pertimbangan nurani (consciousness) pada konteks baik dan buruk, layak tidak layak, serta ukuran kepantasan (morality) atau moralitas.

Mengingat Hakim adalah amanat Undang-Undang, hakim bertanggung jawab terhadap putusannya terhadap Tuhan Yang Maha Esa. Hakim harus bersikap arif dan bijaksana dengan mengedepankan hati nurani, ${ }^{5}$ penulis tertarik mengangkat masalah ini karena banyaknya kasus permohonan poligamiyang sedang menjadi trending topik saat ini. Dimana banyak unsur-unsur dari Undang-Undang mengenai syarat poligami yang tidak dipenuhi oleh pemohon poligami. Dimana dampak psikologis pada istri pertama dan anak-anak darihasil perkawinan pertama sering terabaikan. Hakim harus benarbenar teliti dan hati-hati dalam memberikan ijin terhadap pemohon poligami. Kecuali jika memang syarat absolut dan relatifnya sudah terpenuhi. Secara absolut harus mendapatkan ijin dari istri pertama atau istri-istri sebelumnya dan syarat alternatifnya sudah penulis sebutkan diatas.

Pada banyak kasus permohonan poligami banyak dipicu oleh perselingkuhan yang diketahui oleh istri pertama dengan dalih sudah disahkan dengan perkawinan siri, akhirnya suami meminta istri segera menandatangani menyetujui ijin poligami di

\footnotetext{
3 Permata Press, Undang-Undang Nomor 1 Tahun 1974 tentang Perkawinan, hlm. 78.

${ }^{4}$ Ibid.

5 Bisma Siregar, Hukum Hakim dan Keadilan Tuhan: Kumpulan Catatan Hukum dan Peradilan di Indonesia, Jakarta: Gema Insani Press, 1995, hlm. 80.
} 
Pengadilan Agama. Dimana istri pertama atau yang sebelumnya masih bisa dan mampu memenuhi kebutuhan biologis suami, tidak mendapati sakit yang tidak dapat disembuhkan dan telah mempunyai keturunan. Akhirnya perceraian jadi pilihan terakhir dan anak-anak menjadi korban jika istri pertama tidak mampu mengijinkan dan menjalani poligami.

Pada rumusan masalah kedua penulis menanyakan sudah idealkah pengaturan tentang ijin poligami menurut hukum Islam dan yangterdapat pada UU N0. 1/1974 tentang Perkawinan? Inilah polemik yang sedang terjadi di negara kita. Belum adanya titik temu mengenai perkawinan sah menurut hukum Islam dan hukum Negara. Ini terlihat makin maraknya perkawinan siri dan poligami siri yang menjamur di Indonesia seolah-olah bukan merupakan hal yang pada tahap waspada. Atau UUP yang belum secara tegas mengaturnya, atau aturannya terlalu untuk dilakukan oleh masyarakat kita. Karena dampak yuridisnya sangat kompleks.

Landasan pembentukkan dan pelaksanaan hukum:

1. Nilai kepastian hukum (rhechssicherheit) yaitu hukum harus dilaksanakandanditegakkan. ${ }^{6}$ Dalam hukum perlu adanya kejelasan perilaku yang bersifat umum dan mengikat semua masyarakat termasuk konsekuensi-konsekuensi hukumnya. ${ }^{7}$ Bagaimana hukumnya itulah yang harus berlaku, pada dasarnya tidak boleh menyimpang; fiat justitia et pereat mundus (meskipun dunia ini runtuh hukum harus ditegakkan). Itulah yang diinginkan oleh kepastian hukum, karena dengan adanya kepastian hukum masyarakat tertib, hukum bertugas menciptakan kepastian hukum karena bertujuan untuk ketertiban masyarakat;

2. Nilai keadilan (Gerechtigkeit) dimana hukum itu bersifat umum, mengikat setiap orang, bersifat menyamaratakan, memberikan hasil menurut hukum menjadi haknya memberikan sesuatu yang menjadi haknya, termasuk adil secara psikologis.

3. Nilai kemanfaatan (Zweckmassigkeit) hukum adalah untuk manusia dan harus bermanfaat untuk manusia dalam pelaksanaan dan penegakkannya. Jangan sampai hukum ditegakkan malah menimbulkan keresahan didalam masyarakat.

Setelah dilakukan analisis dan melihat keseluruhan proses yang telah dilakukan dalam proses pembahasan Undang-Undang tentang Perkawinan serta secara subtansial dikaji menurut semuapasal-pasal yang termuat dalam UUP bahwa UUP sudah sempurna yang belum sempurna adalah manusianya sendiri. Dimana UUP tidak memberatkan masyarakat, tidak bertentangan dengan hukum Islam, dan memberikan legalitas kepada seseorang yang melakukan perkawinan, dalam hal ini poligami. Ketentuan Pasal 2 UUP meletakkan fundamentum yuridis perkawinan nasional yaitu dilakukan menurut hukum agama, dan dicatat menurut peraturan perundang-undangan. Berhubungan dengan pentingnya pencatatan perkawinan dalam hukum Islam antara perkawinan dan perzinahan berbeda. Dalam rukun dan syarat perkawinan adalah adanya saksi dan dipublikasikan, bahwa perkawinan itu telah terjadi. Maksud hukum Islam dari adanya publikasi adalah diketahuinya oleh umum bahwa perkawinan telah terjadi dan tidak disembunyikan. Pengumuman tersebut berguna untuk menghindari tuduhan atau keraguan orang lain. Dari penjelasan diatas jelas bahwa hukum Islam pun tidak

${ }^{6}$ Sudikno Martokusumo, Bab-Bab tentang Penemuan Hukum, Cet I, Yogyakarta: Citra Aditya Bakti, 1993, hlm. 1.

7 Achmad Ali, Menguak Tabir Hukum: Suatu Kajian Filosofi dan Sosiologis, Jakarta: PT. Toko Gunung Agung, 2002, hlm. 82. 
menganjurkan terjadinya perkawinan siri atau poligami siri. Demi kemaslahatan bersama.

\section{PENUTUP}

Interpretasi hakim dalam memberikan ijin poligami di Pengadilan Agama sangatlah penting agar tercapainya tiga tujuan hukum secara kepastian, keadilan, dan kemanfaatannya baik dari sisi hukum Negara dan Hukum Islam. Undang-Undang No.1 Tahun 1974 tentang Perkawinan dengan Hukum Islam yang mengatur tentang poligami sudahlah sempurna hanya manusianya sendiri yang belum sempurna dan utuh memahaminya, dimana hukum Islam juga menganjurkan adanya perkawinan yang dicatatkan dan dipublikasikan bukan perkawinan yang disembunyikan demi kemaslahatan semua pihak.

Hendaknya majlis hakim pada Pengadilan Agama lebih arif dan bijaksana dan memperhatikan kepentingan semua pihak terutama istri pertama atau sebelumnya dan anak dari hasil perkawinan sebelumnya agar tercapai tujuan perkawinan yang sakral dan luhur bukan hanya sebagai wadah pemuas nafsu belaka. Sedapat mungkin hindari perkawinan siri dan poligami siri karena dampak negatif baik secara psikologis dan yuridisnya.

\section{DAFTAR PUSTAKA}

Buku:

Ali, Achmad, Menguak TabirHukum: Suatu Kajian Filosofi dan Sosiologis, Jakarta: PT. Toko Gunung Agung, 2002.

Martokusumo, Sudikno, Bab-Bab tentang Penemuan Hukum, Cet I, Yogyakarta: Citra Aditya Bakti, 1993.

Permata Press, Undang-Undang Nomor 1 Tahun 1974 tentang Perkawinan.

Siregar, Bisma, Hukum Hakim dan Keadilan Tuhan: Kumpulan Catatan Hukum dan Peradilan di Indonesia, Jakarta: Gema Insani Press, 1995.

\section{Peraturan Perundang-Undangan:}

Undang-Undang Nomor 1 Tahun 1974 tentang Perkawinan. 